\title{
Does the EU's Drive for Private Enforcement of Competition Law have a Coherent Purpose?
}

\author{
Andreas Stephan ${ }^{1}$
}

\begin{abstract}
This paper argues that the EU's efforts to promote private enforcement in competition law, lack a coherent purpose. The drive to facilitate actions for damages was originally a response to the underdeveloped and diverging nature of private enforcement rules across its Member States. Enhancing deterrence (especially through stand-alone actions) constituted a primary objective at first, but was later abandoned for an emphasis on compensating injured parties. It is argued that the 2014 Damages Directive fails on both counts and may be harming enforcement overall.
\end{abstract}

\section{Introduction}

The Competition Laws of the European Union (EU) have been a major influence on countless jurisdictions around the world, but its strength as a public enforcement regime has always contrasted with a perceived absence of private enforcement. Private parties cannot bring an action for damages or injunctive relief before EU courts. They can only make a complaint to the European Commission or National Competition Authority, to investigate an infringement of competition law, on their behalf. Therefore, a party's ability to recover damages, falls on the national tort and civil liability rules of each Member State. Although most European legal systems can broadly be described as belonging to the Civil Law tradition, there are significant differences in procedure and legal culture when it comes to recovering damages. It is also important to remember that the EU has continued to grow in the last fifteen years, with the accession of ten new Member States in 2004, and a further three in 2007 and 2013. ${ }^{2}$ These include states that have made a rapid transition from centrally planned economies and Communist era legal systems.

\footnotetext{
${ }^{1}$ Professor of Competition Law, UEA Law School, University of East Anglia. Norwich NR4 7TJ, United Kingdom. Email: a.stephan@uea.ac.uk.Twitter: @cartelsman. Blog: competitionpolicy.wordpress.com The usual disclaimer applies. Some of the content of this paper is based on work completed for D Geradin, A Stephan and C Argenton, EU Cartel Law and Economics, forthcoming, Oxford University Press 2018. Chapter V.

${ }^{2}$ Cyprus, Czech Republic, Estonia, Hungary, Latvia, Lithuania, Malta, Poland, Slovakia and Slovenia joined on 01 May 2004. Bulgaria and Romania joined on 01 January 2007. Croatia joined on 01 July 2013.
} 
This paper critically analyses the European Commission's drive to encourage private enforcement of competition law, focusing on the purpose of the 2014 Damages Directive. ${ }^{3}$ It begins by briefly identifying the objectives of private enforcement, the challenges associated with it (Section 2), and the characteristics of US Antitrust Law that incentivise private actions there (Section 3). The paper then turns its focus to Europe, where it outlines the situation before the Directive (Section 4) and then maps how the debate in Europe developed from around 2004; exploring why certain policy areas were abandoned and objectives moved away from enhancing deterrence (Section 5). Finally, the Directive's provisions are mapped against the issues identified earlierin the paper (Section 6). The paper concludes by arguing that the Directive is unlikely to significantly encourage private actions and may even be undermining the effectiveness of public enforcement.

\section{The Challenges of Private Enforcement}

In principle, the private enforcement of competition law serves two useful functions: deterrence and compensation. The first supplements public enforcement, either through the recovery of damages over and beyond public fines (follow-on actions), or by empowering parties to uncover and challenge infringements that have not been subject to public enforcement (stand-alone actions). While follow-on actions essentially amount to an extension of the existing public penalty in the form of damages, it is stand-alone actions that have the greater deterrence-enhancing effect. This is because they result in the uncovering of infringements that might otherwise go entirely undetected. ${ }^{4}$ The second function is to ensure injured parties (be they other firms or final consumers) are compensated for the financial harm they have incurred as a result of the anti-competitive conduct, so that they might be restored to the situation they would have enjoyed absent the infringement.

While very significant sums of money are recovered from undertakings in the form of public cartel fines ( $€ 26.5$ billion in European Commission decisions delivered between 1990-2016), these are paid to Member States and so benefit the general taxpayer. None of this money is used to directly compensate parties affected by an infringement. Indeed, the vast majority of these cases are considered anti-competitive by 'object' under Article 101 TFEU, meaning that effects need not be shown. A Commission Decision in relation to a cartel will not typically attempt to ascertain the extent of the harm caused, or the identity of the injured parties. Often it also fails to establish whether the cartel arrangement was properly

\footnotetext{
${ }^{3}$ Directive 2014/104/EU of the European Parliament and of the Council of 26 November 2014 on certain rules governing actions for damages under national law for infringements of the competition law provisions of the Member States and of the European Union [2014] OJ L 349/1.

${ }^{4}$ See $\mathrm{M}$ Harker and M Hviid, 'Competition law enforcement and incentives for revelation of private information' (2008) World Competition 31(2), pp. 279-298.
} 
implemented. This poses a major obstacle to prospective claimants in follow-on cases, as they must establish both causation and harm.

The challenge of bringing an action for damages is even greater for stand-alone claimants. Cartels are by their very nature secretive agreements, often going to great lengths to hide their manipulation of the market from their customers, the authorities and even others within the same firm. ${ }^{5}$ It is for this reason that around two thirds of cartels uncovered in the $\mathrm{EU}$, are done so as a result of a cartel member self-reporting under the leniency programme. ${ }^{6}$ Those that are not detected through leniency, are uncovered by competition authorities using wide-ranging investigative powers, that include unannounced dawn raids, interviews with employees and powers of seizure. ${ }^{7}$ A private claimant does not enjoy equivalent powers, despite having a higher hurdle to overcome than the competition authority.

A private claimant must also show that they suffered harm as a result of that conduct; something that is far from straightforward. There are important issues such as, whether indirect purchasers should be able to bring an action and, if so, whether the cartel should be able to use passing-on as a defence or in mitigation against a claim. There is also the question of harm caused to those without direct dealings with the cartel, who are not even indirect purchasers. One such category is buyers priced out of purchasing the product altogether, as a consequence of prices being artificially inflated and output restricted. Another is the result of so called, 'umbrella effects', where the cartel's effect on the market price has resulted in buyers paying an artificially high price, even though they are buying from a seller not party to the cartel. ${ }^{8}$

Perhaps the hardest part of the process is accurately estimating damages. In principle, the actual harm caused by a cartel involves examining the counterfactual: what would the price have been absent the cartel? This question can involve a considerable amount of

\footnotetext{
${ }^{5}$ A Stephan and A Nikpay, 'Leniency Decision-Making from a Corporate Perspective: Complex Realities' in C Beaton-Wells and C Tran (eds), Anti-Cartel Enforcement in a Contemorary Age: The Lenniency Religion (Hart Publishing) 2015).

${ }^{6}$ Ibid.

${ }^{7}$ Council Regulation (EC) no 1/2003 of 16 December 2002 on the implementation of the rules on competition laid down in Articles [101] and [102] of the Treaty, OJ [2003] L-1/1,

Articles 17-22.

8 Opinion of AG Kokott in Kone and others v OBB-Infrastruktur, C-577/12, EU:C:2014:45; P Inderst et al., 'Umbrella Effects' (2014) 10, Journal of Competition Law \& Economics, pp. 762-763; D Hansberry et al., 'Umbrella Effect: Damages Claimed by Customers of Non-cartelist Competitors' (2014) Journal of European Competition Law \& Practice 5, pp. 196-205; L Ortiz Blanco, “A Cartel's 'Umbrella Effect' and the Right to Claim Damages for Dalling Under its Shadow: What Does it Change for the Private Enforcement of EU Competition Law?" Thesis. College of Europe, Department of European Legal Studies. Available:

https://papers.ssrn.com/sol3/papers.cfm?abstract id=2813931 (accessed 30 Apr 2018); For a US perspective, see: JM Lave, 'Umbrella standing: the tradeoff between plaintiff suit and speculative claims' (2003) 48, Antitrust Bulletin, pp. 230-234 and RD Blair and VG Maurer, 'Umbrella Pricing and Antitrust Standing: An Economic Analysis' [1982] Utah Law Review, p.785.
} 
speculation, as the counterfactual price will have been affected by a number of factors. For example, cartels typically occur in markets experiencing crisis and can be formed to stop one or more firm in the industry from becoming insolvent. Therefore, the counterfactual price must take into account the possibility of some upward pressure on prices as a consequence of firms exiting the market, thereby making it more concentrated. In practice, courts consider economic evidence provided by each party, but the final calculation of damages can often be better characterised as an estimation employing a series of proxies and assumptions about the market $^{9}$

Given these difficulties, it is worth briefly setting out why the level of private enforcement is so high in the United States.

\section{Private Enforcement in the United States}

In 2006, there were a total of 1,004 Antitrust cases filed in the United States, of which just 37 were public enforcement and 967 were private actions for damages. ${ }^{10}$ While this year may represent a spike in private cases, most US scholars continue to endorse the 1983 Georgetown Study estimate that private actions represent around 90 per cent of all US Antitrust cases. ${ }^{11}$ B By contrast, the number of known private cases in Europe that had been litigated in court by 2001 , could virtually be counted on both hands. ${ }^{12}$

The high level of private enforcement in the US can be put down to a series of factors that, taken together, strongly incentivise prospective claimants to bring an action. These are:

Treble Damages: Claimants in the US can recover three times the harm they suffered. This breaks the general rule in Tort law, that damages should be restitutionary and therefore reflect the actual harm caused. These pecuniary damages can be sought on top of public fines; essentially amounting to a form of double jeopardy, as the purpose of both is to deter. Treble damages strongly incentivise both claims and out of cour settlements. ${ }^{13}$

Favourable Cost Rules: The normal cost rule in the US is that each party pays their own costs. Antitrust cases go a step further, as there is also a one-way cost rule in the Clayton

\footnotetext{
${ }^{9}$ On calculating damages, see: S Bishop and M Walker, The Economics of EC Competition Law: Concepts, Application and Measurement (London, Sweet \& Maxwell 2010), Chapter 17.

${ }^{10}$ See H Hovenkamp, 'Quantification of Harm in Private Antitrust Actions in the United States' (2011) University of lowa Legal Studies Research Paper, citing: Sourcebook of Criminal Justice Statistics Online, covering data of private actions from 1995-2006. Available: http://www.albany.edu/sourcebook/pdf/t5412006.pdf (accessed 30 Apr 2018).

${ }^{11}$ Lawrence J White (ed), Private Antitrust Litigation: New Evidence, New Learning (MIT Press, Cambridge Mass. 1983).

12 J Sinclair, 'Damages in Private Antirust Actions in Europe' 14 Loyola Consumer Law Review 547, $2001-2002$.

${ }^{13}$ R H Lande, 'Are Antitrust “Treble” Damages Really Single Damages?' (1993) 54 Ohio State Law Journal 115.
} 
Act, that favours the plaintiff. ${ }^{14}$ This contrasts with the 'loser pays' principle that dominates legal systems in the rest of the world. The cost rules in the US significantly reduce the risk to bringing an action, by shielding the plaintiff from a significant proportion of the financial risk associated with being unsuccessful. ${ }^{15}$

Joint and Several Liability: Any member of a cartel can be sued for the damage caused by the entire infringement, even if that means paying out more than their 'share' of liability. This means that plaintiffs do not necessarily have to recover damages from the cartel member they had dealings with.

Pre-Trial Discovery Rules: US discovery rules are among the most generous in the world, in allowing prospective plaintiffs to access the documents they need to establish liability. ${ }^{16}$

Class Actions: Law firms in the US can sue on behalf of an entire 'class' of prospective plaintiffs and bring an action on their behalf on an 'opt-out' basis. This means that the claim can seek to recover damages for plaintiffs who have not been specifically identified or sought to be included in the claim. Such cases are especially effective when the harm of the cartel is dispersed among a large number of consumers - each of whom have not incurred a loss of sufficient magnitude to warrant taking action. Most may not even know they have been the victims of anti-competitive conduct.

Passing-on and Indirect Purchasers: Direct purchasers can bring actions for treble damages regardless of whether they passed on some or all of the overcharge to their customers. There is therefore no passing-on defence in US Antitrust law. ${ }^{17}$ To simplify procedures, indirect purchasers do not have standing, although some State Antitrust laws have been amended to allow indirect purchaser standing. ${ }^{18}$

Taken together, these characteristics reflect how the private enforcement of US Antitrust Law has a clear focus on deterrence. The primary function of these actions is not to achieve restitution or to ensure compensation reflects the actual harm caused to injured parties. They stand in stark contrast to the characteristics that dominated national tort regimes in Europe prior to the Damages Directive.

\footnotetext{
${ }^{14}$ Section 4 of the Clayton Act, 15 U.S.C. $\$ 15$

${ }^{15}$ D I Baker, 'Revisiting History - What Have We Learned About Private Antitrust Enforcement That We Would Recommend To Others?' 16 Loyola Consumer Law Review 379 2003-2004, pp. 386-7.

${ }^{16}$ Under Federal Rule of Civil Procedure 26(b) (1), discovery can be obtained with respect to 'any matter not privileged, that is relevant to the claim or defense of any party' including information that would be inadmissible in a court of law. See: G Berrisch, E Jordan and R Salvador Roldman, 'EU Competition and Private Actions for Damages, the Symposium on European Competition Law' (2004) Northwestern Journal of International Law \& Business 24(3), 585, p. 596

${ }^{17}$ Hanover Shoe Inc $v$ United Show Machinary Corp 392 US 481 (1968) at 481

18 Illinois Brick Co v Illinois 431 US 720 (1977)
} 


\section{Private Enforcement in Europe before the Directive}

In 2004, the EU's public competition law enforcement regime reached a point of maturity. The European Commission was enjoying considerable success in its enforcement actions against cartels, thanks in large part to the adoption of a leniency programme in 1996, which was inspired a US Department of Justice scheme. ${ }^{19}$ In the period 2000-2004, almost $€ 3.5$ billion were collected in fines, with the figure set to more than double in the next five years. ${ }^{20}$ The Commission had also dispensed with the cumbersome notification system for agreements seeking an exemption under Article 101(3). ${ }^{21}$ These were instead dealt with through a series of block exemptions and by undertakings assessing for themselves whether a proposed arrangement could benefit from an exception under 101(3). The Modernisation Regulation ${ }^{22}$ allowed Article 101 TFEU to be applied by national competition authorities and courts in full, for the first time, and set out rules for the relationship between EU and national competition rules. The Regulation did not contain any specific provisions on private enforcement, but its preamble noted national courts' responsibility to award damages to the victims of infringements. ${ }^{23}$

Although the European Commission always maintained that it was not seeking to emulate the US system of Antitrust Law, its influence over the development of EU policy during this period is undeniable. As well as leniency and the eventual introduction of a settlement notice, attention began to focus on the apparent low levels of private enforcement. As mentioned in the introduction, while the European Court of Justice ${ }^{24}$ had recognised the right of EU citizens to claim damages for losses caused by cartels, their ability to do so in their own national courts varied significantly between Member States and their incentive to do so was significantly weaker than in the US. It is important to remember that the EU was also expanding at this time and many of its new members were still in the process of harmonising their national laws with those of the EU - for example by adopting leniency programmes.

\footnotetext{
${ }^{19}$ The EU leniency programme was revised in 2002. 'Commission notice on immunity from fines and reduction of fines in cartel cases' OJ [2002] C 45/3

20 Source: European Commission, 'Cartel Statistics'

<http://ec.europa.eu/competition/cartels/statistics/statistics.pdf > accessed 30 Apr 2018.

${ }^{21}$ This allows parties to escape liability under Article 101(1), where they can demonstrate the agreement achieves certain efficiencies for consumers.

${ }^{22}$ Council Regulation (EC) no 1/2003 of 16 December 2002 on the implementation of the rules on competition laid down in Articles [101] and [102] of the Treaty, OJ [2003] L-1/1

${ }^{23}$ Recital 7.

${ }^{24}$ Case C-453/99 Courage Ltd v Crehan [2001] ECR I-6297.
} 
In 2004, the Commission published the Ashurst report on conditions of claims for damages in Member States, in connection with breaches of EU competition rules. ${ }^{25}$ It concluded, 'the picture that emerges from the present study... is one of astonishing diversity and total underdevelopment', noting that only around 60 judged cases for damages were known to have been completed across the EU. The Commission responded to this with a Green Paper on Private Enforcement in 2005. ${ }^{26}$ This was followed up by a public consultation later that year $^{27}$, a White Paper in April 200828, a Commission Staff Working Document in June $2013^{29}$, and a proposal for a directive in that same month. ${ }^{30} \mathrm{~A}$ Directive on antitrust damages actions was signed into law on 26 November 2014, with the purpose of making it easier for EU citizens to claim damages where they were the victims of anti-competitive behaviour. competitive conduct.

Drawing on a number of studies, we can give an overview of the rules that governed private enforcement within EU Member States before the Damages Directive was introduced, and how these differed to the US. ${ }^{31}$ The low number of cases brought in Europe mainly came down to the following factors:

Basis for Bringing a Claim: Some Member States had specifically legislated for a right to bring damages in competition law, while in others there was uncertainty over the basis for such claims. In addition, the decisions of national competition authorities were not generally binding on national courts, making it difficult to bring even a follow-on action. This was a particular problem, given that most national rules required the claimant to establish a strong causal link between the alleged infringement and the loss they uncured.

\footnotetext{
${ }^{25}$ D Waelbroeck, D Slater and G Even-Shoshan, 'Study on the conditions of claims for damages in case of infringement of EC competition rules' Ashurst Comparative Report to the European Commission. (31 August 2004).

${ }^{26}$ European Commission, 'Green Paper: Damages actions for breach of EC antitrust rules' (19 December 2005) $\operatorname{COM}(2005) 672$.

${ }^{27}$ Responses to this are available here: http://ec.europa.eu/competition/antitrust/actionsdamages/green paper comments.html (accessed $30 \mathrm{Apr}$ 2018).

${ }^{28}$ European Commission, 'White Paper on Damages Actions for Breach of the EC antitrust rules' (2 April 2008) COM (2008) 165.

${ }^{29}$ European Commission, 'Commission Staff Working Document - Practical guide on Quantifying Harm in Actions for damages based on breaches of Article 101 or 102 of the Treaty on the Functioning of the European Union. (11 June 2013) SWD(2013) 3440.

${ }^{30}$ European Commission, 'Proposal for a Directive of the European Parliament and the of the Council on certain rules governing actions for damages under national law for infringements of the competition law provisions of the Member States and of the European Union.' (11 June 2013) COM(2013) 404.

${ }^{31}$ What follows is a very general overview of the findings of: The Ashurst Report (n 25); B Rodger, 'Collective Redress Mechanisms and Consumer Case-Law' in B Rodger (ed), Competition Law: Comparative Private Enforcement and Collective Redress across the EU (The Netherlands, Kluwer International 2014); Country reports published by the OECD; Country reports published by the European Commission (2004) - as discussed in Geradin, Stephan and Argenton (n 1), Chapter V.A.
} 
Poor Pre-Trial Discovery: Most Member States had little or no provision for claimants accessing documents, beyond the court's ability to establish factual aspects of the case once proceedings had commenced. Often, even these powers had no teeth to them and the parties responding to a claim could simply refuse. This was not helped by the fact most European laws strongly favour the protection of business confidentiality, over the need to provide civil claimants with access to relevant documents.

Restitution not Deterrence: All national Tort law regimes are designed to ensure parties recover only the actual harm caused. Even in jurisdictions like the UK, where exemplary damages are allowed in principle, courts are very reluctant to award them. For example, in Devenish, ${ }^{32}$ the court refused to award such damages in a follow-on action, because the function of deterrence had already been achieved by the public fine and so pecuniary damages would breach the principle of ne bis in idem (double jeopardy).

Passing on Defence and Indirect Purchaser: Although these issues appeared to be unresolved in many Member States, the commitment to actual and not pecuniary damages, meant that indirect purchasers did, in principle, have standing. It followed from this that a cartelist could invoke a passing-on defence, to argue that the claimant (the buyer) had passed on any overcharge to their customers. In pursuit of actual damages, courts were obliged to ensure there was no unjust enrichment of the claimant.

Loser Pays Cost Rule: This was the standard cost rule throughout the EU and was considered important in discouraging unmerited claims and the use of Tort law to extort money from wealthy businesses who were prepared to settle out of court.

Joint and Several Liability: There was a clear statutory basis for this within some Member States, but not others.

Collective Actions: This was perhaps the weakest aspect of private enforcement in the EU. Most regimes had mechanisms for combining claims, but only where each individual claimant had initiated a claim to begin with. While there were some special procedures for consumer organisations to bring claims, the few collective action mechanisms that existed were firmly on an 'opt-in' basis and so there was nothing equivalent to US class actions.

So in contrast to the US, private enforcement in the European Union was characterised by underdevelopment, a lack of harmonization between Member States and considerable barriers and disincentives for prospective claimants. To fully evaluate the main question in this paper - whether promoting private enforcement in the EU has a coherent purpose - we now turn to the motivation for promoting such actions.

${ }^{32}$ Devenish Nutrition Ltd v Sanofi-Aventis SA [2003] EWHC 2394 


\section{How did policy on private enforcement evolve?}

The European Commission's Green Paper, published in 2005, appeared to emphasise the importance of both the central functions of private enforcement, identified in the introduction: deterrence and restitution. It stated,

'The antitrust rules... are enforced both by public and private enforcement. Both forms are part of a common enforcement system and serve the same aims: to deter anti-competitive practices forbidden by damages caused by them. ...Damages actions for infringement of antitrust law serve several purposes, namely to compensate those who have suffered a loss as a consequence of anti-competitive behaviour and to ensure the full effectiveness of the antitrust rules of the Treaty by discouraging anti-competitive behaviour, thus contributing significantly to the maintenance of effective competition in the Community (deterrence) ${ }^{\prime 33}$

Yet by the time of the of the 2008 White Paper, the primary objective had evolved into, '... [ensuring], more than is the case today, that all victims of infringements of EC competition law have access to effective redress mechanisms so that they can be fully compensated for the harm they suffered. ${ }^{34}$

The deterrent effect of private enforcement was mentioned, but only to the extent that it was a product of improving compensatory justice. What emerged here was a shift from viewing public and private enforcement as jointly pursuing a common objective (deterrence), to their pursuing different, albeit complementary objectives. ${ }^{35}$ The dominant view became that Public enforcement is about deterrence and private enforcement is about compensation. This was reflected in the staff working papers that accompanied the policy documents. The one relating to the Green Paper mentioned 'deterrence' 18 times, going into some detail on how it could be enhanced by private enforcement ${ }^{36}$, while the one relating to the White Paper, mentioned it only in general or complementary terms. ${ }^{37}$ Indeed

\footnotetext{
${ }^{33}$ Commission Green Paper (n 26) at 1.1.

${ }^{34}$ Commission White Paper (n 28) at 1.2.

35 Jones A Jones, 'Private Enforcement of EU Competition Law: A comparison with, and lessons from, the US' in M Bergström, M lacovides, and M Strand, (eds), Harmonising EU Competition Litigation: The New Directive and Beyond (Hart Publishing, 2016); WPJ Wils, 'The Relationship Between Public Antitrust Enforcement and Private Actions for Damages' (2009) 32 World Competition 1, pp. 3-45.

${ }^{36}$ Commission Staff Working Paper, Annex to the Green Paper, Damages actions for breach of the EC antitrust rules $\operatorname{SEC}(2005)$ 1732, for example at B.2, where it says, 'Enhancing private enforcement will maximise the amount of enforcement as a means of enforcement additional to public enforcement. Increased levels of enforcing of the law will increase the incentives of companies to comply with the law, thus helping to ensure that markets remain open and competitive'.

37 Commission Staff Working Paper accompanying the White Paper on Damages actions for breach of the EC antitrust rules, SEC(2008) 404, 2 April 2008, at 2.17 and elsewhere.
} 
the White Paper itself made only one direct reference to the deterrent enhancing benefits of private enforcement. ${ }^{38}$

What also emerges around the time of the White Paper is a realisation of the need 'to preserve strong public enforcement', to ensure the continued success of the European competition authorities' leniency programmes, which ultimately facilitate private enforcement in the shape of follow-on actions (around two thirds of cartels are uncovered by leniency). By the time of the proposed damages Directive in 2013, the objectives had become:

(a) maintain effective public enforcement, by regulating the interaction between public and private enforcement, and

(b) ensure the effective exercise of the EU right to compensation. ${ }^{39}$

As well as ensuring access to justice, these were said to increase the competitiveness of European markets and to remedy a source of fragmentation in the single market. ${ }^{40}$

Policy in the EU was influenced by a number of factors, but the two most significant were the emergence of tensions between public and private enforcement and the intransigence of European legal systems.

\subsection{Public and Private Enforcement}

The Damages Directive had greater scope to promote follow-on rather than stand-alone actions, especially given the European Commission's high level of cartel enforcement activity at the time. Yet, as discussed earlier in this paper, infringement decisions establish guilt, but they do not generally identify the amount of harm or the parties who suffered a loss as a result of the arrangement. Indeed, there is a significant amount of information that is redacted from infringement decisions on the grounds of business confidentiality. Consequently, the information of most use to prospective claimants is that held by the European Commission and national competition authorities. This includes documents submitted through the leniency programme. ${ }^{41}$ Yet allowing claimants to access this information makes leniency less attractive and risks undermining this important investigative tool altogether.

\footnotetext{
${ }^{38}$ See Commission White Paper (n 28)

${ }^{39}$ Commission Staff Working Document 2013 (n 29), p5. European Commission, Proposal for a Directive of the European Parliament and of the Council on certain rules governing actions for damages under national law for infringements of the competition law provisions of the Member States and of the European Union COM(2013) 404, 11 June 2013.at 2-3, as discussed by Wils (n 29) p26.

${ }^{40}$ Commission Staff Working Document 2013 lbid at 71 and 49-55.

${ }^{41}$ See discussion in: S Peyer, 'Disclosure of leniency documents in the United Kingdom: Is the draft directive creating barriers?' (2013) Antitrust Chronicle 8(1), pp.1-8, at 5.
} 
The need to protect leniency programmes came to a head thanks to judicial developments during this period. National courts faced applications to force competition authorities to disclose leniency documents to claimants. The outcome of these legal actions caused considerable confusion and concern. In the case of Pfleiderer, in 2011, the Court of Justice of the European Union (CJEU) passed down a judgement on a preliminary reference made by the Amstsgericht Bonn in Germany. The CJEU recognised that allowing access could compromise leniency, but this could not defeat the well-established right of individuals to bring a claim for damages. ${ }^{42}$ It was therefore up to the national courts and tribunals to consider each application for access to leniency documents on a case-by-case basis, according to national law, and taking into account all the relevant factors in the case. In January 2012, the Amtsgericht Bonn denied Pfliederer's request for access to the Bundeskartellamt's leniency documents. ${ }^{43}$

It soon became clear how the Pfleiderer case-by-case approach risked resulting in significant inconsistency across the very different legal systems of EU Member States. The Commission Staff Working Paper noted how, whereas the German first instance court ${ }^{44}$ in Pfleiderer protected all leniency documents, a German appeal court decision ${ }^{45}$ in a different case and the English High Court judgement in National Grid ${ }^{46}$, only provided partial protection. This meant that leniency applicants had no way of knowing in advance if their submissions would be protected. As predictability and consistency are cornerstones of an effective leniency policy, this development risked deterring leniency applications ${ }^{47}$ The problem was compounded by the fact information contained in leniency documents might be freely exchanged by EU national competition authorities under Articles 11 and 12 of Regulation $1 / 2003 .{ }^{48}$

These concerns were shared by many academics and practitioners who feared that, in its attempt to promote private enforcement, the Commission could fatally undermine the leniency programme that has been the source of so many uncovered cartel agreements. The Commission therefore decided that the Directive should protect leniency and settlement

\footnotetext{
42 Judgment of the Court in Pfleiderer AG v. Commission, C-360/09, 14 June 2011.at 26

${ }^{43}$ See Bundeskartellamt, 'Decision of Local Court of Bonn Strengthens leniency programme' (30 January 2012) Available: http://www.bundeskartellamt.de/wEnglisch/News/press/2012 01 30.php (accessed 30 Apr 2018).

${ }^{44}$ Amtsgericht Bonn (Local Court Bonn), decision of 18-January-2012, case No 51 Gs 53/09 (Pfleiderer).

${ }^{45}$ Oberlandesgericht Düsseldorf (Düsseldorf Appeal Court), decision of 22 August 2012, case No B-4 Kart 5/11 (OWi) (roasted coffee).

${ }^{46}$ National Grid Electricity Transmission Plc v ABB Ltd and Others [2012] EWHC 869 (Ch)

${ }^{47}$ See ECN Model Leniency Programme (November 2012). Available:

http://ec.europa.eu/competition/ecn/mlp_revised 2012 en.pdf (accessed 30 Apr 2018); S D Hammond, 'Cornerstones of an effective leniency program' Presented at ICN Workshop on Leniency Programmes. Sydney, Australia. 22-13 November 2004. Available: https://www.justice.gov/atr/speech/cornerstones-effectiveleniency-program (accessed 30 Apr 2018)

${ }^{48}$ Council Regulation (EC) no 1/2003 of 16 December 2002 on the implementation of the rules on competition laid down in Articles [101] and [102] of the Treaty, OJ [2003] L-1/1,
} 
statements and also that the immune firm (the first to come forward), should be protected from joint and several liability too. Both these decisions were difficult and divisive, with many arguing it went against the Directive's main aim of facilitating access to justice, ${ }^{49}$ while others were concerned that not enough protection was being afforded to firms. ${ }^{50}$

In the US, this same concern about the interaction between public and private enforcement, resulted in the Antitrust Criminal Penalty Enhancement and Reform Act 2004 (ACPERA). ${ }^{51}$ This reduces the immune firm's liability to single damages and removes joint and several liability. It allows the immune firm to settle its liabilities for significantly less than would otherwise be the case. The US system is aided by the fact there is no finding of guilt in relation to the immune firm. By contrast, the immune firm in Europe is still found to have infringed the law and is discussed in the infringement decision. The only practical implication of immunity is that the firm is given a fine of zero.

\subsection{European Legal Systems}

The background documents and consultations to the Directive did spark lively debates about whether it was desirable to facilitate private enforcement, by moving closer to the US model. However, it quickly became clear that there was significant opposition to this within Member States and the European Parliament. The demise of an emphasis on deterrence reflects, in particular, the opposition to mandating pecuniary damages in competition law cases. Apart from floodgate arguments, it quickly became clear that multiple or punitive damages raised serious issues of compatibility with basic and long-standing principles in Tort and Constitutional Law within most Member States ${ }^{52}$, as well as aspects of established Community case law. ${ }^{53}$ These legal traditions are entrenched in principles of compensation for actual harm, which do not allow for unjust enrichment, even if it is on sound policy grounds, such as the need to deter anti-competitive behaviour. ${ }^{54}$ As mentioned earlier, even courts in common law jurisdictions like England and Wales are cautious about abandoning the actual harm principle. There was particularly strong lobbying from the business community, to exclude the availability of punitive damages and opt for a full compensation

\footnotetext{
${ }^{49}$ Their main argument - that protecting leniency documents was inconsistent with the Directive's aim of ensuring compensation and with the interests of transparency - is discussed in C Migani, 'Directive 2014/104/EU: In Search of a Balance between the Protection of Leniency Corporate Statements and an Effective Private Competition Law Enforcement' (2014) Global Antitrust Review, pp. 81-111.

${ }^{50} \mathrm{C}$ Kersting, 'Removing the Tension Between Public and Private Enforcement: Disclosure and Privileges for Successful Leniency Applicants' (2014) Journal of European Competition Law \& Pracice 5(1), 2-5

51 Pub. L. No. 108-237, §§ 201-214, 118 Stat. 666-67 (2004). This was passed by Congress with a sunset clause of 22 June 2010. In May 2010 it was extended for another ten years.

${ }^{52}$ See IAWP (n 40) at 71, citing Renda et al (n 82) Part II, section 1.6.2. See also E Sahin, 'The (Infamous) Question of Punitive Damages in EU Competition Law' (2016) Global Competition Litigation Review.

${ }^{53}$ See discussion of C-344/98, Masterfoods and HB, EU:C:2000:689 in Wils (n 35) p29.

54 The CJEU case law established that, as a minimum, full compensation for victims that should include the loss suffered, including loss of profit and interest. See: Manfredi v Lloyd Adriatico Assicurazioni SpA [2006] ECR I6619at 95 and 97, as cited in Commission White Paper (n 28) at 2.5.
} 
approach. ${ }^{55}$ Respondents to the White Paper consultation, therefore, enthusiastically welcomed the policy of single damages. ${ }^{56} \mathrm{~A}$ key concern that was raised time and time again by a variety of stakeholders, was the seemingly 'apocalyptic' consequences of replicating the US system, in terms of encouraging unmeritorious claims and sparking a 'litigation culture'. ${ }^{57}$

The commitment to full compensation, meant the dye was cast for other key policy issues. Single damages based on a principle of actual harm meant it was necessary to ensure indirect purchasers had standing. In fact, it would have been odd if EU citizens had been deprived standing because they had no direct contractual relationship with the cartel, as access to justice was always a key objective of EU private enforcement (even when there was a stronger emphasis on deterrence), and given that the CJEU had ruled in Manfredi that "any individual" 58 who has suffered harm must be allowed to claim damage. The more significant implication of full compensation, was the availability of a passing-on defence something that was strongly advocated by the business community in the consultations. This was deemed necessary because indirect purchaser standing created the possibility of multiple damages, where an infringing firm is sued for the actual harm by the direct purchaser and for additional damages (for the passed-on overcharge) by indirect purchasers.

\section{How far did the Damages Directive go?}

Directive 2014/104/EU on certain rules governing actions for damages under national law for infringements of competition law provisions of Member States and of the European Union, was signed into law on 26 November 2014 and had to be transposed into Member States' legal systems by 27 December 2016. ${ }^{59}$ Article 3(1) of the Directive established the right set out in Crehan ${ }^{60}$ and created an obligation that 'Member States shall ensure that any natural or legal person who has suffered harm caused by an infringement of competition law is able to claim and to obtain 'full compensation' for that harm' ${ }^{61}$ By virtue of the principles of effectiveness and equivalence set out in Article 4, this right extended to

\footnotetext{
${ }^{55}$ Commission Staff Working Document 2013 (n 29) Annex 8 at 2(e).

${ }^{56}$ Commission Staff Working Document 2013 (n 29) at 7.

57 See editorial: R H Lande, 'The Proposed Damages Legislation: Don't Believe the Critics' (2014) Journal of European Competition Law \& Practice 5(3), 123-4.

${ }^{58}$ Manfredi ( $\mathrm{n} 54$ ) at 61, as cited in Commission White Paper (n 28) at 2.1.

${ }^{59}$ Under EU Law, Directives require Member States to implement laws that reach the result or set of results set out in the Directive. They therefore require implementation, whereas regulations are directly applicable in all Member States.

${ }^{60}$ Case C-453/99, Courage Ltd v Crehan [2001] ECR I - 6297

${ }^{61}$ Directive 2014/104/EU on certain rules governing actions for damages under national law for infringements of competition law provisions of Member States and of the European Union.
} 
both EU and national competition law, to help address the uneven playing field for damages actions the EU. 62

The Directive contained a number of important provisions that will have helped establish a minimum level of harmonization across Member States and deal with the areas of divergence and confusion discussed earlier on. In particular, it required that:

1. Competition authority decisions be binding on national courts and a decision of an authority or court in one Member State should count as at least prima facie evidence of an infringement, for the purposes of an action brought elsewhere in the EU. ${ }^{63}$

2. Minimum limitation periods should exist that should not run until the infringement has ceased and the claimant could reasonably know of them. ${ }^{64}$

3. Courts must have the power to order the disclosure of specified items of evidence, on the basis of facts reasonably available to the claimant. ${ }^{65}$

4. Co-infringers should be held jointly and severally liable for the entire harm caused, with the exception of the immunity recipient. ${ }^{66}$

5. A presumption of harm to assist with the calculation of damages - although this does not relate to a specific sum and so may be of limited value in practice. ${ }^{67}$

6. Alternative dispute mechanisms should be encouraged to reduce litigation costs and widen access to compensation. ${ }^{68}$

These provisions certainly mark significant progress, but the Directive did not tackle some of the more pressing challenges faced by claimants. The commitment to actual damages means the incentive to bring an action remains weaker than in the US. The availability of a passing-on defence is also problematic, as it reduces the inventive for direct purchasers to bring an action. Although this also means indirect purchasers have standing, their ability to successfully bring a claim is hampered by the challenges of establishing a causal link. The provisions of the EU Directive and how it compares to US Antitrust Law, is summarised in the table below

Table 1 - The EU Damages Directive

\begin{tabular}{|l|c|c|}
\hline & EU Damages Directive & United States \\
\hline Damages & Full Single & Treble \\
\hline
\end{tabular}

\footnotetext{
62 See Damages Directive, recitals 8 and 10-11 and Commission Staff Working Document 2013 (n 29) at 49-55.

63 Damages Directive, Article 9.

64 Damages Directive, Article 10.

65 Damages Directive, Article 5.

66 Damages Directive, Article 11.

67 Damages Directive, Article 17.

68 Damages Directive, Article 18.
} 


\begin{tabular}{|c|c|c|}
\hline $\begin{array}{l}\text { Access to } \\
\text { evidence }\end{array}$ & $\begin{array}{l}\text { Disclosure of specified categories, based } \\
\text { on fact-pleading, proportionality }\end{array}$ & Non fact-pleading pre-trial discovery. \\
\hline $\begin{array}{l}\text { Indirect } \\
\text { purchaser }\end{array}$ & Standing allowed & Standing not allowed \\
\hline Passing-on & $\begin{array}{l}\text { Defence allowed; facilitation of proof of } \\
\text { pass-on in favour of indirect purchaser }\end{array}$ & $\begin{array}{l}\text { No passing on defence in Federal Antitrust } \\
\text { law. }\end{array}$ \\
\hline $\begin{array}{l}\text { Effect of NCA } \\
\text { decisions }\end{array}$ & $\begin{array}{l}\text { Commission and NCA decisions binding. } \\
\text { Other NCA decisions at least prima facie } \\
\text { evidence. }\end{array}$ & N/A \\
\hline $\begin{array}{l}\text { Fault (once } \\
\text { infringement } \\
\text { established) }\end{array}$ & Rebuttable presumption. & $\begin{array}{l}\text { Doctrine of 'Antitrust Injury' (no } \\
\text { presumption). }{ }^{69}\end{array}$ \\
\hline $\begin{array}{l}\text { Collective } \\
\text { redress }\end{array}$ & No legislative measures. & 'Opt-out' class actions. \\
\hline Limitation period & $\begin{array}{l}\text { Minimum } 5 \text { years as of reasonable } \\
\text { knowledge }+ \text { restart. Not less than one } \\
\text { year after NCA final decision. }\end{array}$ & $\begin{array}{c}\text { Maximum } 4 \text { years as of reasonable } \\
\text { knowledge. } .^{70}\end{array}$ \\
\hline Cost rule & No legislative measures. & $\begin{array}{l}\text { Parties pay own costs + cost shifting in } \\
\text { favour of claimant. }\end{array}$ \\
\hline $\begin{array}{l}\text { Interaction with } \\
\text { leniency }\end{array}$ & $\begin{array}{l}\text { Leniency and settlement statements not } \\
\text { disclosed. Liability of immune firm limited. }\end{array}$ & $\begin{array}{c}\text { Leniency (immune) firm liability limited to } \\
\text { single damages and protected from joint } \\
\text { and several liability. }{ }^{71} \text { Grand Jury material } \\
\text { tightly controlled. } .^{72}\end{array}$ \\
\hline
\end{tabular}

\section{Has the Directive furthered the aim of compensation?}

If the aim of the Directive ended up being primarily about compensation, then its biggest failure was taking no legislative measures to promote collective actions for damages. This is especially significant given that defendants can rely on a passing-on defence, and the fact the injury caused by anticompetitive behaviour becomes more and more dispersed, the further it is passed down supply chains. In the White Paper, representative actions brought by qualified entities and the introduction of opt-in collective actions, were both mooted. Their purpose was to address the specific concern that individual consumers and small businesses typically had the weakest incentive and faced the greatest barriers, to successfully bringing a claim. ${ }^{73}$ The effectiveness of these measures is far from clear. The experience in EU Member States with existing collective redress mechanisms, was that 'opt-

\footnotetext{
${ }^{69}$ Brunswick Corp. v Pueblo Bowl-O-Mat, Inc., 429 U.S. 477 (1977).

7015 U.S.C. $\S 15 b$.

${ }^{71}$ Antitrust Criminal Penalty Enhancement and Reform Act of 2004

${ }^{72}$ E.g. In re Air Cargo Shipping Antitrust Litigation, 931 F. Supp. 2d 458, 563 (E.D.N.Y 2013); cited by Bill Baer (Assistant Attorney General, Antitrust Division, US Department of Justice), 'Public and Private Antitrust Enforcement in the United States' Speech to European Competition Forum. Brussels, Belgium. 11 February 2014.

${ }^{73}$ White Paper (n 28) at 2.1
} 
in' systems were not effective. Apart from the difficulty of funding such claims in the absence of contingency fees or third party funding ${ }^{74}$, the expense of identifying claimants has proved greater than the sum of money recovered as a result of the claims. ${ }^{75}$

However, the failure of the Directive to legislate for collective actions, had nothing to do with the past experience of such claims within Member States. Neither was it directly down to the intervention of the business community (who were firmly against it). In 2011, the Commission seemed keen to press on with these measures, despite business opposition. ${ }^{76}$ The measures were dropped when the European Parliament delivered a resolution on collective redress in February 2012, which opted for a separate EU framework dealing with collective redress, rather than a competition specific one. ${ }^{77}$ As a consequence, collective redress was omitted from the Directive and the Commission instead issued a non-binding Recommendation that opt-in actions should be adopted. ${ }^{78}$ This was a disappointment to those who had been advocating an 'opt-out' system. ${ }^{79}$ A 2018 report on collective redress recorded how "...the analysis of the legislative developments in Member States as well as the evidence provided demonstrate that there has been a rather limited follow-up to the Recommendation". ${ }^{80}$ The Directive's failure to legislate for such actions may, therefore, represent a significant missed opportunity.

\section{Concluding remarks}

\footnotetext{
${ }^{74}$ A Riley and J Peysner, 'Damages in EC antitrust actions: who pays the piper?' (2006) 31 European Law Review 748

75 See European Parliament Directorate-General for Internal Policies, Collective Redress in Antitrust Study (2012) IP/A/ECON/ST/2011-19 at p36. Discussed in D Geradin, 'Collective Redress for Antitrust Damages in the European Union: Is this a Reality Now?' (2015) 22 George Mason Law Review 1079, 1055. See also: B J Rodger, 'The Consumer Rights Act 2015 and collective redress for competition law infringements in the UK: a class act?' (2015) Journal of Antitrust Enforcement 3(2), pp. 258-286; M Murphy, 'JJB and Which? settle football shirt case' (10 January 2008) Financial Times.

${ }^{76}$ European Commission, Public Consultation: Towards a Coherent European Approach to Collective Redress' (February 2011) http://ec.europa.eu/justice/news/consulting public/0054/sec 2011173 en.pdf Accessed 30 Apr 2018.

${ }^{77}$ European Parliament resolution of 2 February 2012 on 'Towards a Coherent European Approach to Collective Redress' (2011/2089(INI)):

http://www.europarl.europa.eu/sides/getDoc.do?type=TA\&language=EN\&reference=P7-TA-2012-21 (accessed 30 Apr 2018).

${ }^{78}$ Commission Recommendation of 11 June 2013 on common principles for injunctive and compensatory collective redress mechanisms in the Member States concerning violations of rights granted under Union Law (2013/396/EU).

${ }^{79}$ R Gaudet, 'Turning a blind eye: the Commission's r ejection of opt-out class actions overlooks Swedish, Danish and Dutch experience' (2009) 30(3) European Competition Law Review, 107

${ }^{80}$ Report from the Commission to the European Parliament, the Council and the European Economic and Social Committee on the implementation of the Commission Recommendation of 11 June 2013 on common principles for injunctive and compensatory collective redress mechanisms in the member States concerning violations of rights granted under Union Law (2018). COM(2018) 40. P19.
} 
The task of promoting the private enforcement of competition law in Europe was never going to be straightforward. Whilst it is easy to attack the directive, using the US Antitrust law as a benchmark, it was never the EU's intention to replicate that system. Indeed, long standing legal traditions in both civil and common law EU jurisdictions, make that an unrealistic prospect. Given the level of underdevelopment and inconsistency between Member States, the Directive has been very significant in seeking to create a minimum framework for private enforcement. Its consequence is that consumers in every Member State should, in principle at least, be able to bring an action for damages and secure compensation for any loss incurred as a result of an infringement of EU or national competition law.

Yet it is hard to see how the Directive has significantly forwarded deterrence or the compensation objective that it ended up being focused on. The obstacles to bringing an action in Europe remain substantial and the incentives weak. European rules on cost, discovery and passing-on, make the challenges of bringing a stand-alone action against a cartel almost insurmountable. ${ }^{81}$ European legal systems still heavily favour the defendant and any continued growth in private actions is likely to be confined to large buyers affected by cartels, who may have passed-on much of the harm. ${ }^{82}$ Indeed, the only parties who have no way of passing on the harm - the final consumers and smaller businesses - are left with no effective mechanism for recovering damages. Without effectively addressing the position of these most vulnerable of claimants, it is hard to characterise the Directive as a success. Ironically, in attempting to address divergence in rules across Member States, the Directive appears to have sparked greater innovation within some. While most appear to be adhering to the minimum set out in the Directive, others are adopting measures that go a lot further - especially in relation to collective actions. For example, the Belgian Collective Redress Act 2015 , allows a judge to decide whether a collective action should be brought on an opt-in or opt-out basis. Meanwhile, the UK Consumer Rights Act 2015, allows the Competition Appeals Tribunal to allow collective proceedings on an opt-out basis. ${ }^{83}$

Apart from the danger that the Directive neither significantly promotes deterrence, or ensures that compensation is secured by anyone other than large businesses, there is also a danger that the Directive has not gone far enough to protect public enforcement. In contrast to the strong protections that exist in the US, even a firm receiving immunity under

\footnotetext{
${ }^{81}$ On cost rules, see: S Peyer, 'The Antitrust Damages Directive - Much Ado About Nothing?' in R Cisotta an dM Marquis (eds), litigation and Arbitration in EU Competition Law (Edward Elgar 2015); S Peyer, 'The European Damages Directive fails to deliver but can it be fixed?' Competition Policy Blog, 3 March 2015 82 See S Peyer, 'Compensation and the Damages Directive' (2015) Centre for Competition Policy Working Paper 15-10, p29; J Drexl, 'Consumer actions after the adoption of the EU Directive on damage claims for competition law infringements' (2015) Max Planck Institute for Innovation and Competition Research Paper No. 15-10.

${ }^{83}$ Enterprise Act 2002, Section 15(2)(b), as amended by Consumer Rights Act 2015, Schedule 8, Part 2; Rodger (n 75); B McGrath and T Reddy, 'The Consumer Rights Act 2015: full steam ahead for collective procedings?' (2016) Global Competition Litigation Review 9(1), 15-24.
} 
the Commission's leniency programmes, is still subject to a finding that they have broken the law. The possibility of facing large pay-outs in damages may cause some cartelists to think twice before stepping forward. If this indeed proves to be the case, then the drive to increase private enforcement may kill off many of the public enforcement cases that such actions rely on. It may even go some way to explain the decline in cases we have seen. That would represent a significant step backwards in overall enforcement. Only time will tell if the Directive has failed to facilitate a significant increase in private enforcement, while creating sufficient uncertainty to undermine leniency. 